\title{
FLOWERING AND FRUIT-SET RESPONSE TO TEMPERATURE IN THE AVOCADO CULTIVAR 'HASS'
}

\section{SEDGLEY and C.M. ANNELLS ${ }^{1}$}

CSIRO Division of Horticultural Research, Box 350, G.P.O., Adelaide, South Australia 5001 (Australia)

'Present address: CSIRO Division of Horticultural Research, Private Mail Bag, Merbein, Victoria 3505, Australia

(Accepted for publication 29 April 1980)

\section{ABSTRACT}

Sedgley, M. and Annells, C.M., 1981. Flowering and fruit-set response to temperature in the avocado cultivar 'Hass'. Scientia Hortic., 14: 27-33.

Avocado plants, cultivar 'Hass', were kept in growth cabinets at $33^{\circ} \mathrm{C}$ day, $28^{\circ} \mathrm{C}$ night $(33 / 28) ; 25^{\circ} \mathrm{C}$ day, $20^{\circ} \mathrm{C}$ night $(25 / 20)$; and $17^{\circ} \mathrm{C}$ day, $12^{\circ} \mathrm{C}$ night $(17 / 12)$, with a 12 -h photoperiod and photon flux density of $400 \mu \mathrm{E} \mathrm{m}^{-2} \mathrm{~s}^{-1}(400-700 \mathrm{~nm})$. At 33/28 and $25 / 20$ flowers opened in the morning in the female stage and again in the afternoon of the following day in the male stage (Type A floral cycle). At 17/12 the flowers opened in the afternoon in the female stage and started to reopen in the male stage 2 days later during the afternoon. They remained open overnight and started to close the following morning. Pollen tube growth and ovule penetration occurred at all temperatures. Pollen tube growth was fastest at $33 / 28$, but the pistils had lost the ability to support pollen tube growth by the second week of the experiment. A lower proportion of the ovules at $17 / 12$ had an embry osac penetrated by a pollen tube. Embryo development occurred at all temperatures, but fruitlets were abscissed at $33 / 28$ and embryo growth was very slow at $17 / 12$. The most suitable temperature regime for floral behaviour, pollen tube growth and embryo development was $25 / 20$.

\section{INTRODUCTION}

The avocado (Persea americana Mill.) has an unusual flowering-cycle (Robinson and Savage, 1926). The flowers show dichogamy and are functionally female on first opening and functionally male on second opening. Complementary flowering-types allow for cross-pollination to occur. In Type A cultivars, the flower opens in the female stage in the morning. It then closes completely to reopen in the male stage in the afternoon of the following day. The female stage of Type B cultivars opens in the afternoon. After closing overnight, the flower opens in the male stage the following morning. The overall effect of this is that a Type A tree is functionally female in the morning and male in the afternoon and vice versa for a Type B tree. 
Avocado trees often bear poorly or irregularly, and various authors have suggested that adverse temperatures during flowering may be responsible (Bringhurst, 1952; Peterson, 1956; Bergh and Whitsell, 1974). Lesley and Bringhurst (1951) observed that field-grown 'Fuerte' (Type B) trees had no female-stage flowers when the temperature range was between $11.5^{\circ} \mathrm{C}$ minimum and $21.5^{\circ} \mathrm{C}$ maximum. This observation was confirmed by controlled-environment growth-cabinet studies (Sedgley, 1977), when it was shown for 'Fuerte' that the disruption of floral cycle under a $17^{\circ} \mathrm{C}$ day and $12^{\circ} \mathrm{C}$ night resulted in reduced pollen tube growth and no fertilization and fruit development. The normal floral cycle and successful pollen tube growth, fertilization and fruit development occurred under a $25^{\circ} \mathrm{C}$ day and $20^{\circ} \mathrm{C}$ night. With a $33^{\circ} \mathrm{C}$ day and $28^{\circ} \mathrm{C}$ night the floral cycle was normal, but pollen tube growth was inhibited and there was rapid abscission of flowers and fruitlets.

In the case of the Type A cultivar 'Hass' and 'Anaheim', Bringhurst (1951) observed that over a temperature range of $7.5^{\circ} \mathrm{C}$ minimum to $21.5^{\circ} \mathrm{C}$ maximum, the floral cycle was reversed with female-stage flowers opening in the afternoon and male-stage flowers opening in the morning. Bergh and Whitsell (1974) have reported that 'Hass' is less sensitive than 'Fuerte' to low temperatures during blooming and that crop failures under these conditions are less likely in 'Hass' than in 'Fuerte'.

In this study we observed the floral cycle, pollen tube growth and embryo development of 'Hass' under controlled conditions at 3 different temperatures. This was to compare the response with that of 'Fuerte' (Sedgley, 1977) and to provide an explanation for the field observations (Bergh and Whitsell, 1974).

\section{MATERIALS AND METHODS}

Treatments. - Two-year old grafted 'Hass' plants, in which the first floral bud had burst, were kept under 3 different temperature regimes: $33^{\circ} \mathrm{C}$ day, $28^{\circ} \mathrm{C}$ night $(33 / 28) ; 25^{\circ} \mathrm{C}$ day, $20^{\circ} \mathrm{C}$ night $(25 / 20)$; and $17^{\circ} \mathrm{C}$ day, $12^{\circ} \mathrm{C}$ night $(17 / 12)$, with a 12 -h photoperiod $(07.00 \mathrm{~h}-19.00 \mathrm{~h})$ and a photon flux density of $400 \mu \mathrm{E} \mathrm{m}^{-2} \mathrm{~s}^{-1}(400-700 \mathrm{~nm})$. There were 4 'Hass' plants per growth cabinet. One 'Fuerte' plant was kept at 25/20 as a source of pollen.

Floral behaviour. - Each 'Hass' plant was observed for floral cycle, total number of flowers and duration of the flowering-period. Observations were made every 2 hours during the light period and occasionally during the dark period. Each new flower was labelled with coloured cotton.

Pollen tube growth and embryo development. - Female-stage flowers were pollinated by gently brushing the recurved pollen-bearing valve of an anther against the stigma surface. Flowers were pollinated with 'Fuerte' pollen from the $25 / 20$ conditions and also with 'Hass' pollen from the same 
conditions. Recently-closed male-stage flowers were recognised by differentlycoloured labels and the anthers were dissected from the closed flowers.

Twenty flowers were pollinated per treatment and they were collected at $0.5,1,6,24,30$ or $48 \mathrm{~h}$ following pollination, for studies on pollen tube growth.

As large numbers of flowers were required for the pollinations, these were carried out during the first week of peak flowering. This varied under the 3 different temperature regimes (see Table II). The 24-h treatment was repeated during the last week of full flowering. The single ovule was dissected from each pistil and both ovule and pistil were processed for fluorescence microscopy using the aniline blue fluorochrome (Martin, 1959).

Embryo development was followed by removing 5 pistils at 4 and 14 days after pollination. The ovaries were fixed in glutaraldehyde, embedded in glycol methacrylate and stained with periodic acid-Schiff's reagent and toluidine blue 0 (Feder and O'Brien, 1968). Serial longitudinal sections were cut through the embryo at $2.25 \mu \mathrm{m}$ and the number of cells per embryo counted. Embryo development in 'Hass' has been described by Sedgley $(1979,1980)$. Two plants per cabinet were used for pollination and embryodevelopment studies.

\section{RESULTS}

Flowering-data for 'Hass' at the 3 temperature regimes is shown in Table I. Fewer flowers opened at 33/28 than at the 2 other temperatures and the length of the flowering-period decreased with increase in temperature. The average number of flowers opening per day was lower at 17/12 than at the 2 other temperatures.

The mean daily floral cycle of 'Hass' at the 3 temperature regimes is shown in Fig. 1. All flowers went through a female and a male stage. At 25/20 there was considerable overlap between the opening-period of the female and male stages. However, anther dehiscence occurred around $14.00 \mathrm{~h}$, by which time most of the female-stage flowers were closed. At 33/28 the flowers remained open for shorter periods, but again there was some overlap

\section{TABLE I}

Flowering of 'Hass' at 3 different temperature regimes

\begin{tabular}{lrrrr}
\hline & \multicolumn{2}{c}{ Temperature $\left({ }^{\circ} \mathrm{C}\right)$} & \multicolumn{1}{c}{$\begin{array}{l}\text { LSD } \\
(P=0.05)\end{array}$} \\
\cline { 2 - 4 } & $17 / 12$ & $25 / 20$ & $33 / 28$ & \\
\hline $\begin{array}{c}\text { Total number of } \\
\text { flowers opening }\end{array}$ & 1125.0 & 1104.3 & 463.5 & 533.7 \\
$\begin{array}{c}\text { Number of days during } \\
\text { flowering-period }\end{array}$ & 85.3 & 42.3 & 15.0 & 18.8 \\
$\begin{array}{c}\text { Average number of } \\
\text { flowers per day }\end{array}$ & 13.4 & 26.1 & 32.2 & 10.1 \\
\hline
\end{tabular}




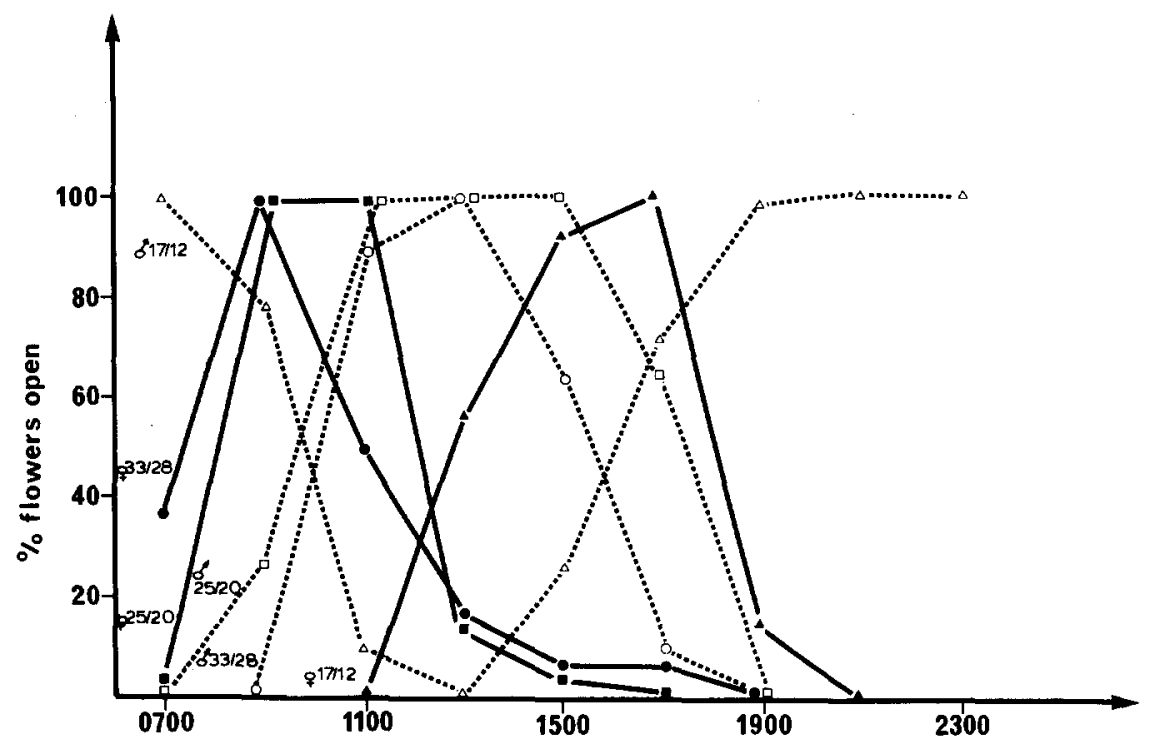

Time of day (h)

Fig. 1. Daily floral cycle of 'Hass' at 3 different temperature regimes.

of the 2 stages. Anther dehiscence occurred around $12.00 \mathrm{~h}$. At 17/12 the opening of the female stage was delayed until the afternoon. The femalestage flowers were closed by $21.00 \mathrm{~h}$ and started to re-open in the male stage 2 days later during the afternoon. Anther dehiscence started around $22.00 \mathrm{~h}$ and the flowers remained open overnight and started to close around $11.00 \mathrm{~h}$ the following morning. At 33/28 and 25/20 the length of the floral cycle was $36 \mathrm{~h}$; at $17 / 12$ it was $72 \mathrm{~h}$.

Table II shows pollen tube growth at the 3 temperature regimes. There was no difference between the results with 'Fuerte' pollen from the 25/20 cabinet and 'Hass' pollen from the same cabinet. The difference in the week of the experiment during which the pollinations were carried out reflects the time taken for the plants to reach and maintain maximum flowering at the 3 temperature regimes. More pollen grains germinated on the stigma at $33 / 28$ and $25 / 20$ than at $17 / 12$, and the pollen tubes grew fastest at 33/28. There was no change in pollen-tube numbers $24 \mathrm{~h}$ after pollination. At 17/12 and $25 / 20$ there was no difference in pollen tube growth at the beginning or at the end of the peak-flowering period. However, at $33 / 28$ fewer pollen tubes would grow in the pistils by the second week of the experiment and there was no ovary penetration.

At all temperatures, a proportion of the pistils had the ovule penetrated by a pollen tube at $24 \mathrm{~h}$ after pollination. The percentage of penetrated ovules was 32 at $17 / 12,95$ at $25 / 20$ and 74 at $33 / 28$. 
TABLE II

Pollen tube growth in 'Hass' at 3 different temperature regimes

Temp. Week of Time after Average number of pollen tubes in

$\left({ }^{\circ} \mathrm{C}\right)$ experiment pollination

(h)

\begin{tabular}{rrll}
\hline Stigma & $\begin{array}{l}\text { Upper } \\
\text { style }\end{array}$ & $\begin{array}{l}\text { Lower } \\
\text { style }\end{array}$ & \\
\hline 19.5 & 11.2 & 0 & 0 \\
16.3 & 9.9 & 0.2 & 0 \\
12.8 & 8.6 & 1.3 & 0.4 \\
10.3 & 6.1 & 1.4 & 0.7 \\
9.3 & 5.1 & 0.9 & 0.4
\end{tabular}

$25 / 20 \quad 2$

824

$\overline{17 / 12} \quad 4$

4

0.5

1

6

24

9.3

$5.1 \quad 0.9$

0.4

$\begin{array}{llll}25.8 & 17.1 & 0 & 0\end{array}$

$\begin{array}{llll}22.7 & 15.8 & 0.2 & 0\end{array}$

$\begin{array}{llll}33.1 & 21.5 & 2.3 & 1.1\end{array}$

$\begin{array}{llll}44.7 & 23.6 & 1.9 & 1.0\end{array}$

$\begin{array}{ccc} & 4 & 24 \\ 33 / 28 & 1 & 0.5 \\ & & 1 \\ & & 6 \\ & 24 \\ & 2 & 24\end{array}$

LSD

$(P=0.05)$

$\begin{array}{llll}34.4 & 18.0 & 2.1 & 0.9\end{array}$

$\begin{array}{llll}23.4 & 13.0 & 0.5 & 0\end{array}$

$\begin{array}{llll}23.4 & 13.0 & 0.5 & 0 \\ 26.9 & 16.6 & 2.2 & 0.8\end{array}$

$\begin{array}{llll}31.5 & 17.9 & 3.1 & 0.6\end{array}$

$\begin{array}{llll}31.5 & 17.9 & 3.1 & 0.6 \\ 26.6 & 15.6 & 2.1 & 0.8\end{array}$

$\begin{array}{llll}17.2 & 9.0 & 0.2 & 0\end{array}$

$\begin{array}{llll}8.7 & 4.3 & 1.4 & 0.6\end{array}$

\section{TABLE III}

Embryo growth in 'Hass' at 3 different temperature regimes

\begin{tabular}{llc}
\hline $\begin{array}{l}\text { Temperature } \\
\left({ }^{\circ} \mathrm{C}\right)\end{array}$ & \multicolumn{2}{l}{$\begin{array}{l}\text { Average number of cells per embryo } \\
\text { at } 4 \text { and } 14 \text { days following pollination }\end{array}$} \\
\cline { 2 - 3 } & 4 days & 14 days \\
\hline $17 / 12$ & 0.6 & 3.2 \\
$25 / 20$ & 1.6 & 48.8 \\
$33 / 28$ & 2.4 & - \\
LSD & 1.5 & 22.7 \\
$(P=0.05)$ & &
\end{tabular}

Table III shows embryo growth at the 3 temperature regimes. Some embryo development occurred under all 3 temperature regimes. By 14 days, all the $33 / 28$ fruits had been shed and there was a large difference between the cell numbers of the embryos developing at $25 / 20$ and $17 / 12$. 


\section{DISCUSSION}

Floral cycling, pollen tube growth and embryo development occurred at all 3 temperature regimes tested. The $25 / 20$ conditions were most favourable as fruitlet abscission occurred at $33 / 28$ and embryo growth at $17 / 12$ was extremely slow. This is in contrast with the response of 'Fuerte' (Sedgley, 1977), where abscission of unopened flowers occurred at $33 / 28$ and fertilization did not take place at $17 / 12$.

There was considerable overlap in the opening of the female and male floral stages at all temperatures, but anther dehiscence did not occur until most of the female-stage flowers had closed. There was little opportunity for self-pollination at any of the temperatures. At 17/12, the length of the floral cycle was doubled. This did not prevent pollen tube growth and fertilization although fewer ovules were penetrated than at the higher temperatures.

Pollen tube growth in the pistil did not change over the period of peak flowering at $25 / 20$ and $17 / 12$. At $33 / 28$, however, the flowers became less able to support pollen-tube growth with increasing time under the experimental conditions. Thus, the higher temperatures appeared adversely to affect the physiology of the flowering plant more than the lower temperatures. This was also shown by the total number of flowers opening under the 3 conditions. Fewer flowers opened at 33/28 than at the 2 other temperatures. Very little abscission of floral branches or unopened flowers was observed, indicating that abortion of unburst floral buds may have been occurring. Thus the flowering 'Hass' plant could successfully withstand short periods of high temperatures, but prolonged exposure would adversely affect fruit set and development. Short periods of temperatures over $30^{\circ} \mathrm{C}$ are experienced during the avocado flowering period in some areas of Australia (Alexander, 1975).

'Hass' has been reported to yield more consistently than 'Fuerte' (Bergh and Whitsell, 1974). This may be due partly to the fact that penetration of the embryosac is more efficient in 'Hass' than in 'Fuerte' (Sedgley, 1979). A further reason may be the greater tolerance of the breeding-cycle of 'Hass' to a wider range of temperatures. It is possible that there is a physiological difference in temperature-response between Type A and Type B cultivars. Peterson (1956) reported that fewer Type B than Type A cultivars would bear well in the cool coastal areas of California. Confirmation of such a physiological difference requires further research. Nevertheless, a difference in floral response to temperature between 'Hass' and 'Fuerte' has been established. Thus, the choice of predominant cultivar must depend at least in part on the temperatures during flowering in the area under consideration.

\section{ACKNOWLEDGEMENTS}

The authors wish to thank Don McE. Alexander for helpful discussion and for providing the grafted 'Hass' plants, and Sue Porter for technical assistance. 


\section{REFERENCES}

Alexander, D.McE., 1975. Flowering times of avocados in the Murray Valley. J. Aust. Inst. Agric. Sci., 41: 264-267.

Bergh, B.O. and Whitsell, R.H., 1974. Self-pollinated Hass seedlings. Calif. Avocado Soc. Yearb., 1973-74: 118-126.

Bringhurst, R.S., 1951. Influence of glasshouse conditions on flower behaviour of Hass and Anaheim avocados. Calif. Avocado Soc. Yearb., 1951: 164-168.

Bringhurst, R.S., 1952. Sexual reproduction in the avocado. Calif. Avocado Soc. Yearb., 1952: 210-214.

Feder, N. and O'Brien, T.P., 1968. Plant microtechnique: some principles and new methods. Am. J. Bot., 55: 123-142.

Lesley, J.W. and Bringhurst, R.S., 1951. Environmental conditions affecting pollination of avocados. Calif. Avocado Soc. Yearb., 1951: 169-173.

Martin, F.W., 1959. Staining and observing pollen tubes in the style by means of fluorescence. Stain Technol., 34: 125-128.

Peterson, P.A., 1956. Flowering types in the avocado with relation to fruit production. Calif. Avocado Soc. Yearb., 1956: 174-179.

Robinson, T.R. and Savage, E.M., 1926. Pollination of the avocado. U.S.D.A. Circ. 387: $1-16$.

Sedgley, M., 1977. The effect of temperature on floral behaviour, pollen tube growth and fruit set in the avocado. J. Hortic. Sci, 52: 135-141.

Sedgley, M., 1979. Light microscope study of pollen tube growth, fertilization and early embryo and endosperm development in the avocado varieties Fuerte and Hass. Ann. Bot., 44: 353-359.

Sedgley, M., 1980. Anatomical investigation of abscissed avocado flowers and fruitlets. Ann. Bot., 46: in press. 